\title{
Dialectics of Sacrificing and Worshiping Animals in Hindu Festivals of Nepal
}

\author{
Bishnu Prasad Dahal \\ Department of Anthropology, Patan Multiple Campus, Tribhuvan University, Patan Dhoka, Nepal \\ Email: phd.bishnudahal@gmail.com
}

How to cite this paper: Dahal, B. P. (2020). Dialectics of Sacrificing and Worshiping Animals in Hindu Festivals of Nepal. Advances in Anthropology, 10, 97-124. https://doi.org/10.4236/aa.2020.102007

Received: March 21, 2020

Accepted: April 27, 2020

Published: April 30, 2020

Copyright (๑) 2020 by author(s) and Scientific Research Publishing Inc. This work is licensed under the Creative Commons Attribution International License (CC BY 4.0).

http://creativecommons.org/licenses/by/4.0/

\begin{abstract}
The aim of this paper is to explore the basic trend of dialectic in animal worshipping and sacrificing in Nepali cultural festivals; mainly worshipping and sacrificing dialectics, material and spiritual dialectics: from early date to the present day. This can never be denied that it is dialectics or contradictory approach which might be thought to be the basic tenet of its socio-scientific ameliorations. Dialectics, here, is used as to be synonymous with contradictions or debate, mainly in the behavioral pattern of people in specific culture. Dialectics is used as the gap between idea cultural beliefs and behavior of people in Hindu cultural context. From Hegalian dialectic perspective to Marxist dialectic perspective and even if Harris dialectic model of cultural materialism, it is found that Dashain and Tihar, what we are celebrating nowadays, are dialectic materialistic in nature. It has great significance ecological, economic and adaptive socio-culturally, bio-psychological, but still it is perceived as religiously. Religion provides societal glue, because it offers people meaning and purpose for their lives and it gives certain values and meanings. That's why people believe in religion either for "hope" or by "fear". In fact, religious rituals are practices required or expected of members of a faith. Rituals usually honor the divine power (or powers) worshipped by believers; the) also remind adherents of their religious duties and responsibilities. Both worshipping and sacrificing animals or cattle in cultural context are determined by their dialectism in it.
\end{abstract}

\section{Keywords}

Dialectic, Worshiping, Sacrifice, Dashain, Tihar., Religion, Cultural Ecology, Dialectical Anthropology, Symbolic Anthropology, Socio-Cultural System, Etic, Emic 


\title{
"Festival is what a culture makes; celebration what People make."
}

\author{
Popular Nepali Saying
}

In this paper, I attempt to indicate certain prevailing dialectical interpretation of ecological use of cattle in Nepali festivals mainly Dashain and Tihar.

\section{Introduction}

Nepal is multilingual, multicultural and multi-ethnic country. When we go back throughout the Nepalese history that we can find it out, it depends on syncretism of various cultures, languages, religions, castes and ethnics. It is a garden of all castes and ethnic groups. Immediately, south of the Himalaya is attractive mountain valley. This region is inhabited by various Tibeto-Burman and Indo-Ayan speaking hills and valley people. Its altitudes are between 3500 and 7000 feet above sea level. The climate is cold temperate to warm temperate. Sixty percent people of the country live in this region.

To the south of the region, there is a stretch of land which consists of the low river valleys and unhealthy forest belts are inhabited by various indigenous people whose origins and affinities are quite obscures. Here, as is the case in the high Himalaya, there are fewer inhabited areas than in the middle ranges. Also lacking is the charm of the mountain surroundings at higher altitudes. The altitude is 1000 to 2500 feet above sea level (Bista, 1987).

\subsection{Dialectical Anthropology: Overview}

In this paper, the work is focused to explore or juxtapose the dialectical framework used in cultural events and phenomena in Hindu festivals Dashain and Tihar. My concern in this paper is to understand the cultural phenomena, events etc. through dialectic perspectives, mainly in Dashain and Tihar.

Anthropologists' theoretical and empirical analysis has generally been based on the assumption that societies can be seen as persistent, cohesive, stable, generally integrated wholes differentiated by their cultural and social structural arrangements in a way and in another way, society and cultures are dynamic. These contradictory components of understanding variations ultimately help to draw the dialectical anthropology to understand society and culture. In dialectical anthropology, it is possible to identify the role of social environment, conditions, situations, realities on social actions through the comprehensive perspective. The cultural values and attitudes, activities, relationships of society are shaped by the structure of society composed of parts/elements. Ultimately, dialectical anthropology helps to provide wider vision to understand social reality and facts on it.

Dialectics has been widely used in Greek philosophy, and it was the art of knowing truth by uncovering the contradictions in reasoning of one's adversary. According to Hegalian school, dialectic is both a way of thinking or thought that stresses the importance of processes, relations, dynamics, conflicts and contra- 
dictions, a dynamic rather than a static way of thinking about the world. Similarly, on the other hand, it is a view that the world is made up of static structure; processes, relationship, dynamics, conflicts and contradictions (Craib, 1997). Likewise, idealism emphasizes the importance of mind and mental products rather the material world, i.e. ideas. Hegal concentrated on the development of such ideas, which he called the "spirit of society". Hegal understood what is the sensed by five organs of the human is the socio-physical world. But, there were lacking of feelings or emotions and self understanding what they did. In my opinion, dialectical approach is a contradiction between what people are (real) and what they feel (idea). But, Feuerbach was critic of Hegal and emphasized on consciousness and spirit of the society that people attended or concentrated on material reality than subjective idealism.

In Dialectical anthropology, philosophical background was propounded by Marx by synthesizing the concepts from Hegal's and Feurebach's ideas and argued new idea i.e. "dialectical materialism". Marx concentrated his ideas on materialistic interpretation of history through a distinctive "dialectic methods". Two most important elements from two thinkers were extracted by Marx; Hegal's dialectic and Feuerbach' materialism and fused them into his own distinctive orientation, dialectical materialism which focuses on dialectical interplay within the material world.

Dialectical anthropological analysis has also focused on subsistence behavior within and environmental context and demographic variables were always seen as a part of the relationship. Population adaptation is determined by exploring, how much exploitative behavior influenced other aspects of culture, including demography, settlement patterns, ownership structures, land tenure and land use. The adaptation of population or the population transitions depend on the socio-culture matrix of fertility behavior of both human and non-human populations. Dialectical anthropological is different from the classical cultural ecology not only in terminology but also in perspectives. Dialectical anthropological analysis based on ecological anthropology is a return and advance from previous neo-functionalist and neo-evolutionist schools represented by Rappaport, Steward and White, although it incorporates many of the same issue of human and environmental interaction.

Dialectical anthropological concept is well explained by Harris in his studying cultural materialism. He argues that the universal structure of socio-cultural systems rests on the available bio-psychological systems (here in my paper sacrificing and worshipping animal) mainly related with: People need to eat and will generally choose diets (especially cattle products; meat and milk) that offer more rather than fewer calories and proteins and other nutrients (Magnarella, 1982).

Harris explains that the universal structure of socio-cultural systems rests on the distinction between thought and behavior and emics and etics. There is interplay between technology and food production, according to the Harris, it stands as the infrastructure of the socio-cultural system. The technology and 
practices employed for producing food and other forms of energy, including technology of subsistence, techno-environmental relationships, ecosystems, work patterns, etc. (Magnarella, 1982). Likewise, the technology and practices employed to regulate population size, including demography, mating patterns, fertility, mortality, nurturance of infants, medical control of demographic patterns, contraception, abortion, infanticide, etc. and the nature of various factors which are involving in the respective socio- natural system with the help of socio- structural patterns including the organization of reproduction and basic production, exchange and consumption within domestic settings, including family structure, domestic division of labor, domestic enculturation, age and sex roles, domestic discipline, hierarchies, sanctions, etc. (Magnarella, 1982).

Another preposition of dialectical anthropological is political economy according to Harris, which incorporates the organization of reproduction, production, exchange, and consumption within and between bands, villages, chiefdoms, states, and empires. It includes political organization, division of labor, taxation, tribute, political enculturation. class, caste, urban and rural hierarchies, discipline, police/military control, war, etc. including art, music, dance, literature, advertising, rituals, games, science, etc. (Magnarella, 1982).

In this paper, my prime concern is to how people apply dialectic approach to adopt in their socio-natural system and socio-cultural system. From the cultural materialists view, they have established the some rules in their socio-cultural system and they completely follow it because they are the part of that socio-natural system in a way. And in another way, they should depend on the components where they live. The main focus of this paper is identify the mechanism of dialectics by following the rules of culture in one hand i.e. idealism of worshipping animals and in another hand, they should sacrifice the animals for their desire of hungry or say food i.e. material reality.

\subsection{Dialectical Anthropology and Religion}

"Dialectic" refers to the methodology that "there is a strong Hegelian strain in the way even the simplest peoples organize and utilize categories for the purposes of religious expression (Leach, 1968). Before going to documentation of the task of religious rituals, first of all we have to define religion; Durkheim was perhaps the first thinker to recognize the critical importance of religion in human societies. In his view "religion is a collective act and includes many forms of behaviors in which people interact with others". Durkheim initiated sociological analysis of religion by defining religion as a "unified system of beliefs and practices relative to sacred things". Compromising the definition put forward by Durkheim, I want to raise the question, "How can human societies be held together when they are generally composed of individuals and social groups with diverse interests and aspirations?" The probable answer may be that "religious bonds often transcend these personal and diverse forces". But readers may have further questions "Why should religion provide the societal glue?" Religion pro- 
vides societal glue because it offers people meaning and purpose for their lives. It gives them certain ultimate values and end to hold in common. Although subjective and not always fully accepted, these values and ends help a society to function as an integrated social system. That's why people believe in religion either for "hope" or by "fear". In fact religious rituals are practices required or expected of members of a faith. Rituals usually honor the divine power (or powers) worshipped by believers also remind adherents of their religious duties and responsibilities.

Generally, in dialectical anthropological explanations, there are two different schools which study about the religion. One of them is the school studies about the "Sociology of Religion" through which school importantly put forward the explanation of the symbols, ritual and practices of religion in relations to the structure of society. The main premises of the school are that the sociological research is concerned with how religion is used to help or keep society together or in order? How it helps to maintain in the status quo or whether it can help to bring about changes in society or not? There are two different founding scholars and followers, who argue about sociology of religion. Funtionalists and their followers believe on religion as an organ in organism, a sub-system within the system, an inter locking and necessary institution, which play a role in the creation and maintenance of the value consensus. Similarly, Marxist and their followers believe on that religion is formed so as to create the inequality in societies through idea of "ruling class" over "ruled class", while anthropology of religion concentrates on a study in cultural theory and demonstrate that order, harmony, and resolution should not be privileged in conceptualizations of culture at the expenses of contradiction, tension and irresolution.

Studies in Nepal about religion either through the anthropological or through sociological or history or through only other perspectives have declared that, studies only uncertainly on religions like Hinduism, Buddhism and their practices or in spirit possession with one's own perspective. But, there is lacking of holistic perspectives, through which, everyone can understand the relations of people in their socio-political and cultural psychological dimensions.

Clifford Geertz - pioneering figure in the symbolic anthropology - recognizes anthropology as the science of culture. Geertz's interpretive anthropology claims to be a scientific study; however it must be able to excavate or dig out the meanings.

Symbols usually signify many things: to use Turner's phrase (1967) they are multi-vocal. According to Geertz, human behavior is fundamentally symbolic and therefore laden with meaning for social actors. The primary task of ethnographer is to understand the "webs of significance" which people themselves have spun.

Symbolic/interpretive ethnography focuses on the meaning of behavior and rely primarily on verbal data in support of their interpretations. So, it is not inaccurate to say symbolic ethnographies have been similar to neo-structural in 
style.

Geertz in "thick description" argues the aim of anthropology is to interpret the meaning of behavior to explain actions and attitudes that appear puzzling. According to him, culture consists of "structures of significance". "Frame of interpretation" or "socially established structures of meaning". For Geertz, culture is "context" and it is the object of the ethnography to describe it.

Clifford Geertz is the architecture of symbolic anthropology- is not an experimental science in search of science in search of law but an interpretive science excavating the meanings. He says that the concept of culture is essentially a semiotic one that man is an animal suspended in webs of significance (meaning) he himself has spun.

Geertz views that culture is those web of meanings, analysis of which can be made through interpretation in search of meaning in the social and cultural context. He perceives of the meanings as being shaped by, and shaping, people's actions. Culture is interpreted through "thick description" but the "thin" one. Hence, the job of anthropologist is to explore the meaning of the action of the individuals in a culture and expose the layers of the culture- to provide the thick description.

In dialectical anthropological studies, according to Geertz, culture is not something locked into people's mind; rather it is embodied in the public symbols-symbols through which the members of a society communicate their world views value orientation, etc., symbols that shape influence their activities, consciousness and so on. Symbols are vehicles of meaning which act like windows through which we can see, understand the culture being studied. For example, how Dashain gives meaning about kinship structure in the society-food symbols, Jamara and its relation with agriculture, purity/impurity, again all context, based, hence need "thick description" to understand the culture.

The culture is public, because meaning is public. It is expressed in symbolic actions and meanings are contextual. So, culture contexts (actions become meaningful only within the contexts in which they are operated; meanings may change in another context). For example, "chair" in the classroom and "chair" in politics.

The Geertizan model of symbolic anthropology focuses on the meaning of the cultural activities not to functions per see. Such activities are analyzed to open up meanings of other aspects of the culture (like Balinese Cock fight and the Rituals of Nyugne in Sherpa society). For Geertz, the idea about a culture is like a literary text that can be analyzed for meaning, as the ethnographer interprets. Like ethnographers, cultural interpretations, try to convey, the symbols of culture and their meanings to those, people who are really interest about their own culture or those who are interplaying within this cultural context. Therefore, according to Geertz, the ethnographer is a kind of selective inter-cultural translator.

Some anthropologists think that, interpretation is the only achievable goal in cultural anthropology, because they do not believe it is possible to describe or 
measure cultural phenomena in objective or unbiased ways.

\subsection{Dialectical Anthropology and Ecology}

In general, we can say that the anthropological explanation of environmental with human behavior is human ecological anthropology which is dialectical in nature and consists of the relationships between socio-cultural system and environment by means of technological and a social organizational adaptation. Since ancient times, there have been many theoretical approaches to explain the relationships between environment and human behavior. Both eastern and western philosophers like Aristotle, Montesquieu insisted such kind of relationships in more philosophical manner. But after the development of natural sciences such as biology, geography, physics along with sociology and anthropology. In the latter part of the $19^{\text {th }}$ century, the subject has been more systematized and scientific. From past to the present days, a number of very different conceptual approaches have been employed in human-ecological anthropology to understand human and environment interactions.

The way a population organizes itself for survival in a particular environment of habitat, such organization resulting in a spatial distribution of subsistence activities determined by time, energy costs and accessibility variables (Hawley, 1950). Human ecology's main task is the analysis of such community structure. The variables in the analysis are structural properties, demographic attributes, and features of environment, including interactions with other systems. Dialectical anthropology investigates the ways that a population shapes its environment and environment to population in the subsequent manners in which these relations form the population's social, economic, and political life (Salzman \& Attwood, 1996). In a general sense, ecological anthropology attempts to provide a materialist explanation of human society and culture as products of adaptation to given environmental conditions (Seymour-Smith, 1986).

As parallel with ecological anthropologists, I would like to analyze the energy input in the model of subsistence or technology and social institutions of work to collect and produce food in local ecosystem where Dashain and Tihar. festivals were celebrated. All of this was set within the biological framework of limiting factors and carrying capacity. Components of culture especially non material cultures such as religions or religious ceremony/occasion (Dashain) that helped to maintain a balance between populations (human and non-human) and its resources. In my observation of religious occasions and ceremonies as regulating the delicate balance between human and non-human (pigs, sheep, goats and other cattle) population and to reduce competitions between these species could be compared with the study of Vayda and Rappaport. It is observed that humans and non-humans are surprisingly close in physiology, body and group size and in the omnivorous diet pattern suggesting the similar way of exploiting (modes and means) natural resources on one way and festivals also maintain to establish the morality of the society and religious beliefs of people in society in another 
way.

However, Rappaport believe that the following statement by Homans (1941) represents fairly the dominant line of dialectical anthropological thought concerning the functions of religious ritual. Ritual actions do not produce a practical result on the external world-that is one of the reasons why we call them ritual. But, to make this statement is not to say that ritual has no function. Its function is not related to the world external to the society but to the internal constitution of the society. It gives the members of the society confidence, it dispels their anxieties, and it disciplines their social organization.

Another dimension of dialectical anthropological explanation of religion as culture in Leslie White's term "we find that progress and development are affected by the improvement of the mechanical means with which energy is harnessed and put to work as well as by increasing the amounts of energy employed" (Bohannan \& Glazer, 1988). Later on the study about the interrelationship between culture and ecology as discipline -cultural ecology converted in the new discipline "ecological anthropology-a new schools of thought, including the ecosystem model, ethno-ecology, and historical ecology (Barfield, 1997). The ecological anthropology and the study of adaptations would provide explanations of customs and institutions now a day to study the interaction between and among them (Salzman \& Attwood, 1996). Ecological anthropologists believe that populations are not engaged with the total environment around them, but rather with a habitat consisting of certain selected aspects and local ecosystems (Kottak, 1999). Despite these, population became the key factor to analyze the interplay between ecology and culture because; each population has its own adaptations institutionalized in the culture of the group, especially in their technologies (Salzman \& Attwood, 1996).

But it remained for Steward to emphasize the importance of culture and its effects on the environment, in a sense to relegate the natural habitat to the role of dependent variable in determining the life ways of the group, society, or region. Unlike Steward's cultural ecology that focuses on reciprocal causality between two objects or processes (i.e. between environment and cultural components or cultural core) Geertz's concept focuses on complete set of mutual causality that is between man, plants and animals along with non-living environment. Thus, cultural system theory believes that an adaptive process is required by particular human population's survival within particular environment. So, cultural features are studied in terms of the possible contribution they make for population's adaptation to its ecosystem rather than as being part of coherent systems in their own right.

In course of studying cultural materialism, Harris widely used the concept of dialectical anthropological framework to describe "the principle of techno-environmental and techno-economic determinism. This principle holds that similar technologies applied to similar environments tend to produce similar arrangements of labor in production and distribution, and that these in turn call 
forth similar kinds of social groupings, which justify and co-ordinate their activities by means of similar systems of values and beliefs. The principle of techno-environmental, techno-economic determinism and assigns priority to the study of the material conditions of socio-cultural life, much as the principle of natural selection assigns priority to the study of differential reproductive success" (Harris, 1979).

As a part of local ecosystem, people worship and sacrifice animals in their culture, which animal gets priority in worshipping and which will get target to sacrifice is different according to the needs and available ecosystem this is one of the dialectical definition of the material reality of the world which we call it as a culture. Mainly people who worship the animal culturally will not sacrifice in their religious rituals. The Hindu religion recognizes the rights of animals to co-exist with humans; therefore, people are taught to love, nurture and worship them. Human will not worship those animals even if they get similar benefits in the ecosystem. It is mainly determined by morality of that society. Similarly, the religion promotes the belief that various Hindu gods and goddesses incarnate in various animal forms. In the past, kings and emperors used various species of animals in their emblems to show their respect. Many festivals in India and Nepal are still being celebrated to honor different animals (Agoramoorthy \& Hsu, 2006).

Harris's basic approach to the study of culture is to show how emic (native) thoughts and behaviors are a result of material considerations. Harris focuses on practices that contribute to the basic biological survival of those in society (i.e., subsistence practices, technology, and demographic issues). In order to demonstrate this point, analysis often involves the measurement and comparison of phenomena that might seem trivial to the native population (Harris, 1979). Harris used a cultural materialist model to examine the Hindu belief that cows are sacred and must not be killed. First, he argued that the taboos on cow slaughter (emic thought) were superstructural elements resulting from the economic need to utilize cows as draft animals rather than as food (Harris, 1966). He also observed that the Indian farmers claimed that no calves died because cows are sacred (Harris, 1979). In reality, however, male calves were observed to be starved to death when feed supplies are low (Harris, 1979). Harris argues that the scarcity of feed (infrastructural change) shaped ideological (superstructural) beliefs of the farmers (Harris, 1979). Thus, Harris shows how, using empirical methods, an etic perspective is essential in order to understand culture change holistically with full of dialectical anthropological framework.

Thus, dialectical, in a broad sense of the term, is expressed here as a dialogical phenomenon that exposes the substantial debates and discussion between two diametrically opposed cultural attitudes, norms and values and even thoughts. Hindu oldest scripture Veda, for example, expresses different paradox belief which reflects the socio-cultural, politico-economic and ethno-cultural sphere of Nepal. Present works and deeds of Indian scholar's mark several vestiges to 
substantiate this claim. Nepali culture, attitudes, norms, values and thoughts, thus, in every respect, is full of divergent faiths and profound human convictions. This paper will explore, here, the basic trends of the attitudes, norms, values, thoughts or say culture; broadly both materials and non- materials cultures, on which all Nepalese speculations are firmly based upon.

\section{Methods Employed}

Both etic and emic perspective with participant observation methods were used mainly in anthropology so as to identify the dialectic of using various cattle or animals in the ecosystem where dominant Hindu religious people with other religious people celebrate the Dashain and Tihar, as their holy and great festivals. Even though non Hindus are also celebrating these festivals with ignoring to religious function of worship but they follow and celebrate these festivals for enjoyment and family gathering to socialize their new generations culturally. That's why, worshipping animals and sacrificing animals associated with these festivals have great significances not only religiously but economically and ecologically too. Methodologically, festivals are the part of socio- cultural phenomena and within these cultural practices in the base of religion; there are so many contradictions and controversy associated with festivals and its associates.

Widely used concepts etic and emic perspectives are usually applied to analyze the socio-cultural, politio-economic and religio-ecological phenomena associated with culture based on ecosystem, energy flow, carrying capacity, nitch etc. An etic view of a culture is the perspective of an outsider looking in. non-Hindus along with others use this concept to study Hindu festivals Dashain and Tihar, in relation with the ecological significance to worshipping and sacrificing the animals would be from an etic standpoint usually, do not integrate themselves into the culture they were observing. While studying the Dashain and Tihar, through the etic perspective, information that is related with the festivals from outsider's opinion is gathered by using various tools and techniques including observation, interaction that may be superficial for such research topic. It may also fail to identify, diagnose, assess and correlate the causal factors associated with them. It is very hard to know the real facts and its correlation with their local social, economical, ecological and religious along with psychological systems integrated in cultural phenomena for an outsider.

Whereas, local knowledge with their perspective, fact based information commonly termed as emic view of culture is ultimately a perspective focus on the intrinsic cultural distinctions that are meaningful to the members of a given society. Indigenous people with their own understanding in terms of their own cultural system with their own perspective with their own language to understanding the interaction between and within cultural system, economic system and ecological etc. are often considered to be an "insider's" knowledge and understanding with their own perspective. While this perspective stems from the concept of immersion in a specific culture, the emic participant isn't always a 
member of that culture or society, he/she may be out from the society and culture but need to understand the facts about that and may know the reason behind these and may know the process and procedure that prevailing inside them.

Studies done by using an emic perspective often include more detailed and culturally rich information than studies done from an etic point of view. Because the observer places themselves within the culture of intended study, they are able to go further in-depth on the details of practices and beliefs of a society that may otherwise have been ignored. In another hand, sometimes the emic perspective usually create bias on the part of the participant, especially if said individual is a member of the culture they are studying, thereby failing to keep in mind how their practices are perceived by others and possibly causing valuable information to be left out. Usually, etic perspectives are treated as value judgment and their ethos that may cause bias and is also dominated by ones' own perspective or understanding as superficial and surface arguments but there is very low chances in emic perspective. While the emic perspective serves the purpose of providing descriptive in-depth reports about how insiders of a culture understand their rituals. That's why this research follow participant observation, interaction, key informants' interview are used to generate information to analyze the sociocultural analysis through emic perspective to identify the correlation between religious component and ecological significance in particular culture.

\subsection{Participant Observation}

Purposively two festivals Dashain and Tihar, were selected as analytical unit so as to easy and valid to elaborate, and juxtapose the festivals events to compare and contrast the dialectic method to identify the existing situation and reason behind it with one another through participation observation methods. Researcher is also a member of the society where the cultural festivals are celebrating every year. As a participant observer researcher has tried to maintain the ethics so as to easy to visualize the cultural processes without biasness. It has also helped to explore the reason behind the question: why animals were worshipped in some festivals and some were sacrificed in another. Actually, why animals were worshipped and why sacrificed were explored by participating on festivals thoroughly and tried to explore the reason behind these-whether religious or any other else.

\subsection{Dialectics as a Method}

In the history of anthropological thoughts dialectical method comes into prominence in Hegelian approach although its root is firmly based upon Grecian old thoughts. Plato's approach to the truth is rather argumentative. In abstract, dialectism begins when people attended or concentrated the materialistic philosophy, material reality and physical development of this world based logic, science and technology rather than subjective idealism. That's why one of the schools presented the arguments on it and another school criticized the argument by 
counter arguments based on reality, logic and science etc. In this way, "dialectics" is especially taken as a method of arguments, where two antagonistic subjects are reconciled through the process of agreement and disagreement with each other. Hegel clearly advocates that there can never be any thought if it lacks the similarity and dissimilarity in any form.

According to the Marxist dialectism, "dialectal" suggests three dimensions to thinking. The first is the notion of the whole or the totality-the idea that over knowledge can be judged by its inclusiveness, the extent to which it gives a knowledge of the totality of what we are studying... i.e. unity in diversity (Cuff et al., 1990). Here, the knowledge about diverse elements unite is a kind of dialectical in nature, but from the perspective of functionalist, they unit for their corresponding/mutual needs with each other. The second dimension is an elaboration of the development of thought which is usually attributed to Hegal. In another word, thought(history itself) progresses through stages; a thesis, an initial proposition, an anti thesis- the opposite to the thesis and a synthesis-a result of the argument which combines both thesis and anti thesis which in turn becomes the thesis for new movement (Craib, 1997). The third dimension of the notion dialectic is that contradiction and movement; a society is not a simple entity but a combination of contradictory elements in a permanent process of change. Contradiction, conflict and change are seen as normal and evitable aspects of social development (ibid). This paper try to explore the existing contradictions, conflicts and changes are seen as normal and inevitable aspect of social development as researcher is trying to analyze the worshiping and sacrificing the animal in Hindu festival with various reasons whether reason may be the religious or cultural base or through the ecological base. Marxian, Hegelian and new synthesis concepts are the appropriate to visualize the dialectic concept in worshiping and sacrificing animals in Hindu festivals- Dashain and Tiha, as dialectical anthropological concept which can appropriately assess the socio-cultural and politio-economic and ecological significance of the Hindu festivals through the perspective of dialectical materialism.

\section{Study Area}

This research was conducted among Hindus who celebrated Dashain and Tihar, that held on September and October, 2019 in Kathmandu, Dashain and Tihar, were selected purposively to identify the similar and different cultural and religious customs and processes. 100 households were chosen as representative for the study randomly who celebrate Dashain and Tihar, as festivals. 100 households were selected for the representation for unit of qualitative analysis where, animals were sacrificed in Dashain Ghar during Navaratri and animals were worshipped in Tihar, 100 households were selected and for the unit of qualitative analysis so as to easy to explain dialectics in animal worshipping and animal sacrificing.

Similarly, semi-structured interviews were carried out among 100 samples 
household and their senor most member either male of female were selected as respondent randomly, where Dashain was celebrated with the sacrifice of animals/cattle and Tihar, with worshipping animals.

Semi-structured interviews were conducted in Nepali language with respondents. It is very easy to conduct research through participant observation because researcher is from Hindu religious background and is a resident of study area.

\section{Findings and Discussions}

The goal of dialectical anthropological perspective is to interpret or to open the cultural events and phenomena into different meaning according to time, context and conditions. First of all, many anthropological classical schools and modern anthropological schools, tries to familiarize the readers with the particular culture while dialectical anthropological school tries to interpret the same culture into different situation with different meanings. Here, dialectics of worshipping animal and sacrificing animal can be illustrated as;

\subsection{Sacrificing and Worshipping Animals: Non-Materialistic Perspectives}

Studies in Nepal about religion either through the anthropological or through sociological or history or through only other perspectives have declared that, studies only uncertainly on Hinduism, Buddhism and their practices or in spirit possession with one's own perspective. But, there is lacking of holistic perspectives, through which, everyone can understand the relations of people in their socio-political and cultural psychological dimensions.

Practices of Hindu animal sacrifice are mostly associated with Shaktism, and in currents of folk Hinduism strongly rooted in local tribal traditions. Animal sacrifices were carried out in ancient times in Nepal and India. Hindu scriptures such as the Gita (Robinson, 2014) and some Purans forbid animal sacrifice (Preece, 2001).

Good and evil were elaborately explained in epic stories of Bhagavad Gita and in Mahabharata. In these stories there were very nice combination of contradictions episode to juxtapose in modern life mostly in Hindu society and culture. When the battle of Kuruksertre is inevitable and Arjuna is much more confused about his duty, he expresses his extreme reluctance in fighting with them. However, he does accept the advice through a long consultation with his master and friend. Arjuna's rejection at the outset and acceptance of Krishna's advice later follows the rule of dialectics: thesis antithesis and synthesis. The teaching of Gita reaches at almost every part of the Hindu world not only as a religious scripture but also for its profundity in critical human recognition as well (Preece, 2001). After the advice from Krishna to Arjun there were contradictions, confusions and conflict on many things that was also kind of the dialectic. Then material and non material world of Hindu people were ultimately influenced from those 
dialectic ideologies, mainly on the worshipping and scarifying animal in their feasts and festivals. From the religious epic texts, it is claimed that: non-material cultures associated with religious rituals are essentially spiritual but basic mode of this thought associated with material cultures i.e. with non-spiritual elements. Secondly, Hindu cultures, norms, values, attitudes, thoughts and cultures, wherever it is expressed, especially in ancient literature and epic, must follow the basic trends of development i.e. material development and that is dialectics. Thirdly, Early Nepalese scripture reflects the cohesion between Vedic and non-Vedic philosophy. And this special trend comes from the society comprising the Aryan people and their cultures and non-Aryan people with their cultures.

\subsection{Modes of Nepalese Life and its Cultural Significance}

Various religious dimensions and ritual differentiations are an integral problem for theory of religion. Usually, anthropology of religion and their followers including historicians have traditionally approached. Multifaceted ritual systems from two primary vantages; which Kirsch, A. Thomas (1967) mentioned about the religious complexity in the south and southeast Asian Buddhist society, commonly found in Thailand. His main theoretical preposition is that in Buddhist societies uses the rituals as the strategies for their adjustment, adaptations or for their livelihood in microscopic perspective in one way and while in another way, Buddhist societies view or understand the rituals as they have same structures (processes, components, feelings, roles, responsibilities etc.) and their functions to maintain the society stable. Kirsch avoided seeing rituals and feasting simply as part of the traditional cultures of "tribal" groups and, instead, saw them as being dynamically connected with the negotiation and contestation of social arrangements and rank. In the field of Thai studies, his influence was considerable. Under these two circumstances, anthropologists and historician, can interpret the meanings of symbols i.e. action and reactions, how people act, react and perceive in socio-psychological spheres of human life.

Parallel, with Geertzian analysis in "Bali", many anthropologists defined the "great tradition" and "little tradition" while studying the Asian religion, like Geertz's "thick description" and "thin descriptions". According to the anthropologists "great tradition" means usually text based religious practices such as Hindu or Buddhist practices, and according to them, "little" means a residual set of practices, associated by divinities and spirits not found in the great tradition.

Studies in Nepal about religion either through the anthropological or through sociological or history or through only other perspectives have declared that, studies only uncertainly on Hinduism, Buddhism and their practices or in spirit possession with one's own perspective. But, there is lacking of holistic perspectives, through which, everyone can understand the relations of people in their socio-political and cultural psychological dimensions. Here I just want to visualize these perspectives through dialectic interplay between material and non material cultures. 
In Nepal due to harsh ecological condition the defined niches has limited resources- fertile soil/land grazing land, forest products, so the people employed herding, agriculture and other domestic small-scale cottage industries as economic strategies and were forced to live at a bare subsistence level. People are transhumant, as they are mobile with their own occupations-agriculture, herds and petty trades ensuring easy livelihood. When winter comes they migrate towards the low altitude valley along with their cattle for protection from the cold as well as to manage the scare resources. When summer comes they move reverse along with their livestock. In this way, cultural ecological study of that society recognized or indicated that environment and culture (all sphere of life) are not separate spheres but is involved in "dialectical interplay" or "reciprocal causality". So, I like to argue that there is a cause and effect relationship between "livelihood strategies" of and "ecological resources availability or conditioning" as one influences the other. Here, importantly in the Hindu festivals Dashain we can visualized the scare resources due to the climate (higher the altitude longer will be the harvesting period and lower will be the productivity) and other various factors reciprocally interdependent with each other, then society has established such cultural institutions as the agent to maintain delicate balance between population and resources acts as dialectically.

It is very difficult to transplant the one theory from its own cultural context to other contexts, so, I here do not want to emphasize the factors that are material and play key role to determine the culture as Julian Steward has done, but it complements the Stewardian model by synthesizing the system model propounded by Andrew Vadya and Roy Rappaport. Here, it follows Vadya and Rappaport's paradigm of human ecology including population as a unit of analysis-"ecosystem or ecology as the context and adaptation as the dynamic process of interaction between population and ecosystem".

It is needed to analyze the energy input in the model of subsistence or technology and social institutions of work to collect and produce food. All of this was set within the biological framework of limiting factors and carrying capacity. Components of culture such as religions or religious ceremony or occasion mainly Dashain and Chaitra Astami that helped to maintain a balance between populations (human and non-human) and its resources. My observation regarding to the religious occasions and ceremonies as regulating the delicate balance between human and non-human (pigs, sheep, goats and other cattle) population and to reduce competitions between these species could be compared with the study of Vayda and Rappaport. It is observed that humans and non-humans are surprisingly close in physiology, body and group size and in the omnivorous diet pattern suggesting the similar way of exploiting (modes and means) natural resources. That's why the interplay between human and non human population is also found dialectic and it follows both Stewardian "cultural ecology" and partly the Vadya and Rappaport's population ecology i.e. "ecological anthropology". He neither duplicates the Stewardian model nor adopts 
the population ecology. Overwhelmingly, I really want to synthesize both the models in appropriate way for the study of sacrificing animals in Dashain and worshiping animals in Tihar, of Hindus of Nepal.

It is necessary to define a subsistence economy as the situation where flow of inputs and outputs becomes more or less equal. Meeting the subsistence demands and social religious requirements (life cycle, rites, festivals, ritual ceremonies, exorcism) using their own modes and means is the condition of subsistence. Here, the inputs of the system are human and animal labor, cash and goods from trading ventures, and existing physical and biological resources where as the outputs are production of goods (animals, cottage industry, and agriculture products), labor outside the city, village, abroad and surplus goods and cash.

The allocation of resources and products are based on the existing ecological constraints and potentials of the system. Fundamental to Barth's assumptions, it is agreed on the facts that man tends to maximize his environment in the choice of strategies discovering the differential constraints on the economic system. There should be reasons for use of certain economic strategies and allow one to predict directions in which a community can and may move economically.

\subsection{Dashain Festival in Nepal}

Dashain the greatest festival of Hindus of Nepal usually celebrated during the month of Kartik (late September and early October), the Nepalese people indulge in the biggest festival of the year. Dashain is the most auspicious and longest festival in the Nepalese annual calendar, celebrated by Nepalese of all caste throughout the country. The fifteen days of celebration occurs during the bright lunar fortnight ending on the day of the full moon. Thorough out the Nepal the goddess Durga in all her manifestations are worshiped with innumerable pujas, abundant offerings and thousands of animal sacrifices for the ritual holy bathing, thus drenching the goddess for days in blood.

The victory of Ram over Ravana is the celebration of Dashain in Nepal. One of the victory stories told is the Ramayan, where the lord Ram after a big struggle slaughtered Ravana, the fiendish king of demons. It is said that lord Ram was successful in the battle only when goddess Durga was evoked. The main celebration glorifies the triumph of truth or good over false or evil and is symbolized by goddess Durga slaying the terrible demon Mahisasur, who terrorized the earth in the guise of a brutal water buffalo. The first nine days signify the nine days of ferrous battle between goddess Durga and the demon Mahisasur. The tenth day is the day when Mahisasur was slain and the last five days symbolize the celebration of the victory with the blessing of the goddess. Dashain is celebrated with great rejoice, and goddess Durga is worshiped throughout the kingdom as the divine mother goddess. Dialectic concepts are very interestingly woven in Hindu texts that evil characters "rakhchesh" are always killed by goddess. In patriarchy worshiping goddess in patriarchal society is dialectic in nature which helps to 
maintain the equilibrium between goddess and patriarchy system where son gets high priority and male is the head in every decision. Here, it is great contradictions that I found, without help of goddess Durga Ram did not get success, then why women are not getting such values in decision making process in household and in public sphere? Worshiping goddess in orthodox Hindu patriarchy system is one of the dialectic.

Dashain is celebrated by preparing home clean and beautifully decorated, painted as an invitation to the mother goddess; symbol of power, so that she may visit and bless the house with good fortune. During this time, the reunions of distant and nearby relatives occur in every household. The market is filled with shoppers seeking new clothing, gifts, luxuries and enormous supplies of temple offering for the gods and goddess, as well as foodstuffs for the family feasting. Thousands of sheep, goats, ducks, chicken and water buffalo are prepared for the great slaughter. Schools, colleges and many organizations are closed for ten to fifteen days, few organizations remains open from Ghatasthapana to Fupati, then all remains closed during Fulpati to Kojagrat Purnima.. Laborers are almost impossible to find; from the poor to the rich, all enjoy the festive mood. Anywhere you go the aroma of "Vijaya Dashami" is found.

The first nine days of Dashain are called Nawa Ratri when tantric rites are conducted. In Nepal the life force is embodied in the divine energy and power of the female, depicted as goddess Durga in her many forms from the beginning of the Nawa Ratri, patriarchy and male worship the goddess Durga (the goddess represent the world of women) in one hand women are suppressed, exploited and dominated in the same home and in the same festival. What are the significance of worshiping goddess Durga by exploiting women in same home? All goddess who emanated from goddess Durga are known as Devis, each with different aspects and powers. In most mother goddess temples the deity is represented simply as a sacred Kalash, carved water jug or multiple handed goddess holding murderous weapons. During these nine days people pay their homage to the goddess. If she is properly worshiped and pleased good fortunes are on the way and if angered through neglect then misfortunes are around the corner. Mother goddess is the source of life and everything in one hand and such mothers are excluded to provide the rights and authority in another.

Ghatasthapana is the first day of Dashain is celebrated by established pot in Dashain Ghar in each household. On this day the Kalash, (holy water vessel) symbolizing goddess Durga often with her image embossed on the side is placed in the prayer room. The Kalash (full of water vessel) is filled with holy water and covered with cow dung on to which seeds are sown. A small rectangular sand block is made and the Kalash is put in the centre. The surrounding bed of sand is also seeded with grains. The Ghatasthapana ritual is performed at a certain auspicious moment determined by the astrologers. At that particular moment the priest intones a welcome, requesting goddess Durga to bless the vessel with her presence. Worshiping Dashain Ghar by male priest to the goddess Durga with- 
out permission to enter inside to the female is also dialectic in nature.

The room where the Kalash is established is called "Dashain Ghar". Generally women are not allowed to enter the room where Dashain Puja is being carried out. A priest or a household man worships the Kalash everyday once in the morning and then in the evening. The Kalash and the sand are sprinkled with holy water every day and it is shielded from direct sunlight. By the tenth day, the seed will have grown to five or six inches long yellow grass. The sacred yellow grass is called "Jamara". It is bestowed by the elders atop the heads of those younger to them during the last five days when Tika is put on. The Jamara is taken as a token of Goddess Durga as well as the elders blessing.

As days passes by regular rituals are observed till the seventh day. The seventh day is called "Fulpati". In Fulpati, the royal Kalash filled with holy water, banana stalks, Jamara and sugar cane tied with red cloth is carried by Brahmans on a decorated palanquin under a gold tipped and embroidered umbrella. The government officials also join the Fulpati parade. With this the Dashain feasting starts.

The favor of worship and sacrifice to Durga and Kali increases in the eighth day which is called the Maha Asthami. On this day many orthodox Hindus will be fasting. Sacrifices are held in almost every house throughout the day. The night of the eighth day is called "Kal Ratri", the dark night. Hundreds of goats, sheep and buffaloes are sacrificed at the mother goddess temples. The sacrifice continues till dawn. While the Puja is being carried out great feasts are held in the homes of common people where large amount of meat are consumed. Usually, females are not allowed to enter the Dashain Ghar or Puja area and even in most of the cases they are not allowed to watch the Puja ceremony too. But virgin females are worshiped by offering Tika before the distributions of $\mathrm{Pu}$ ja Parsad, is also another dialectics.

Another important day of Nawa Ratri is Nawami. It is also the last day of Kaal Ratri. Temples of mother goddess are filled with people from dawn till dusk. Animals mostly black buffaloes are slaughtered to honor Durga the goddess of victory and might and to seek her blessing. Military bands play war tunes, guns boom and officers with beautifully decorated medals in full uniform stand there. When the function ends the courtyard is filled ankle deep with blood. On this very day the god Vishwa Karma, the God of creativity is also worshiped. All factories, vehicles, any machinery instruments and anything from which we make a living are worshiped. We also give sacrifices of animals to all machines like cars, aero planes, trucks etc. to get the blessing from goddess Durga for protection for vehicles and their occupants against accidents during the year. The entire day is colorful.

The tenth day is the Dashami which is the most important day of the whole festival. On this day we take Tika and Jamara from our elders and receive their blessing. We visit our elders in their home and get Tika from them while our younger ones come to our home to receive blessing from us. The importance of 
Dashain also lies in the fact that on this day family members from far off and distant relatives come for a visit as well as to receive Tika from the head of the family. This function continues for four days. After four days of rushing around and meeting your relatives Dashain ends on the full moon day, the fifteenth day. In the last day people stay at home and rest. The full moon day is also called "Kojagrata" meaning "who is awake". The Hindu goddess of wealth Laxmi is worshipped. On this day the goddess Laxmi is given an invitation to visit each and everyone.

Table 1 shows that, during field work, 35\% Newars, 31\% Chhetri are followed by Brahmin, Tamang, Gurung, Rais and others as $11 \%, 6 \%, 5 \%, 4 \%$ and $2 \%$ respectively. Here, it is found that, the caste group or ethnic groups, who use liquors mostly, sacrifice animals in Dashain.

Table 2 shows that, goat is the most common animal to sacrifice during $\mathrm{Da}$ shain. Here, it is found that, during Navaratri, people sacrifice multiple animals, goat is the common for all caste and ethnic groups, except goat sheep, buffaloes, chickens, ducks and even pigs were sacrificed and consumed.

According to Department of Livestock Services, Traders used to import 4000 goats per week during normal times. After the government has asked the traders to produce health examination certificates of the livestock, but traders deny

Table 1. Distribution of respondents who sacrifice cattle in Dashain by caste and ethnicity.

\begin{tabular}{cccc}
\hline S.N. & Caste and Ethnicity & Respondent & Percentage \\
\hline 1 & Brahmin & 17 & 17 \\
2 & Chhetri & 31 & 31 \\
3 & Newar & 35 & 35 \\
4 & Tamang & 6 & 6 \\
5 & Gurung & 5 & 5 \\
6 & Rais & 4 & 4 \\
7 & Others & 2 & 2 \\
& Total & 100 & 100 \\
\hline
\end{tabular}

(Source; Field Work, 2019).

Table 2. Distribution of numbers of animal sacrifices within sample households.

\begin{tabular}{cccc}
\hline S.N. & Type of animals sacrifices & No. of animals sacrifices & Household \\
\hline 1 & Goats & 85 & 70 \\
2 & Sheep & 10 & 10 \\
3 & Buffaloes & 3 & 3 \\
4 & Chickens & 40 & 40 \\
5 & Ducks & 5 & 5 \\
6 & Others & 2 & 2 \\
\hline
\end{tabular}

(Source; Field Work, 2019). 
taking health certificate, they are importing at least 200 goats illegally on daily basis. The demand of the goat during Dashain festivals in the Kathmandu Valley stands at 50,000 live goats, in September, 2019, and it is estimated that 25,000 extra goats will be supplied to Kathmandu for Dashain from different parts of the country (Kathamndu Post, 14, September, 2019).

After Dashain everyone settles back to normal. After receiving the blessing of goddess Durga, people are ready to work and acquire virtue, power and wealth. Dashain thus is not only the longest festival but also the most anticipated one among all the festivals of Nepal.

\subsection{Tihar Festival in Nepal}

Tihar marks the victory of truth or good over false or bad and is the most widely celebrated festival in Nepal, Tihar is called the Festival of Lights, Diwali or Sukhrantri, Deepavali or Diwali is spread across 5 days in various regions of the country. It does generally fall at the end of October. In south Nepal, Madhesh or Terai people celebrate Deepavali to mark the victory of Lord Ram over demon King Raavan.

Among the Newari culture, the festival of Tihar holds a special importance. On this day, the New Year starts on the Newari culture named Nepal Samvat. On the day of Laxmi Puja, they celebrate Mha Puja or self worship. They worship their own body and soul.

Another major reason to celebrate Tihar, festival in Nepal is harvesting cereals. The festival also holds a special importance to farmers across the agriculture based country like Nepal. Tihar marks the end of the harvest season, which is why the farmers celebrate it.

Another epic story is also associated with Tihar a legend Dipawali has that the lord King of Death -Yamraj went to his sister and stayed there for five days. His sister heartily welcomed him and offered Tika and garland round his neck. Further, she provided him with delicious food, she wished for his peace, progress and long life. That's why; the sisters do worship the Yamraj before worshipping their brothers at Tihar. It is believed that the life span of the brothers lengthens if they do worship the Lord King of Death.

Worshiping Crow or Kag Tihar, is the first day of Tihar. Nature worship is an important aspect of Hinduism as different animals, plants and geography are taken as the rides, manifestations, and abodes of the gods. People offer delicious foods, Tika and many more to the crows on this day. The first day of Tihar, is called Kag (crow) Tihar, because crow is worshipped on this day. Crow is believed to be the messenger of the underworld king Yamaraj, so its worship is supposed towards the evil of death and grief. Crows are in, cunning birds, yet people hail them at this festival. They opine that they are the angels or messengers who fetch tidings. In Nepal, according to the Hindu mythology about crow or Kag, it is restricted to touch crow but they worship crow ignoring more numbers of species of various Aves available in Nepal specific references to their 
uses and utilization in their society, culture and even in ecology. Ecologically, crows also play a vital role in process of pollination and seeds spread from one to another places. Many ripen seeds are spreading by many Aves including crow as their food and undigested seeds inside the Aves' exceed ultimate spread in new places. In appropriate environmental conditions it is germinated. In our country, worshipping crow symbolizes and represents the most of the Aves that are found in our ecology as a part of component and specific species. That why, it is also the remarkable dialectics about worshipping crow in Tihar without touch and restricted to touch it. Reason behind worshiping crow may breed of crow takes relatively more time than other Aves available in local ecosystem. Worshipping crow in one hand and restricted to touch crow in another hand is also the dialect in nature.

The second day of Tihar festival is Worshiping Dog or Kukur Tihar. Worshiping dog in Hindu festival Tihar is called Kukur Tihar as a symbol of worshiping honest animal commonly named kukur (dog), can also be understood as part of the nature worship. Dogs are garlanded around their necks and given the delicacies. Dogs are believed to be the gatekeepers of the underworld king Yamaraj, so its worship is in the belief of placating Yamaraj. On this day, people worship the dog as Vehicle of God. The main importance of Dog Puja in Nepal is the giving thanks to dogs, supposed the vehicle of God and guard of the home in every moment. They safeguard our houses and properties. They are supposed the faithful animals. So, people put Tika in the dogs' forehead and garland round their neck. They also give them food to eat. Those who have no pet dogs at home also worship the street dogs on this day. Ecologically, street dogs eat human exceed (stool) to make environment clean while people used open toilet. From the energy flow perspective the unutilized and undigested food in human exceed is tapped by street dogs to make environment clean in one hand and in utilized unutilized energy in a ecosystem as a consumer. Interestingly, dog is honest and faithful animal which is used as security of human, that's why it is worshipped in Tihar, but people abandoning, abusing and neglecting pets (or any other animal for that matter). It is dialectic approach that, the rampant suffering of dogs despite living in a society that worships them.

This is perhaps the most spectacular day of Tihar. In the morning cow (Gai) is worshipped. In the Hinduism, cow is taken as the symbol of prosperity and wealth. In the evening, people make an extravagant display of lights in and out of their house to worship Laxmi, the goddess of wealth. Laxmi is believed to abhor darkness and like light, so numerous candles are lit in every nook and corner of the houses and even in the courtyard outside. Youth send firecrackers in the sky, and troops of young girls called Bhaileni move from house to house invoking the blessings from gods. The households donate money and other offerings because that it is believed to be an auspicious moment for donating and these donations are believed to multiply the prosperity.

In this most auspicious day, people take bath in the early morning, take fast- 
ing the whole day, and in the evening time they worship the Goddess Laxmi, the Goddess of wealth. So, in the morning people worship cows. Cows are thought as an incarnation of Goddess Laxmi. In the evening, people worship an image or picture of Laxmi and invoke her blessings. Broom is also worshiped because it helps keep the home clean and clear.

People especially the children knock door to door chanting cultural songs and dances called Deusi and Bhailo to collect money for charity or for them. It is believed that people can have a huge pile of wealth if Goddess Laxmi is pleased. So, they keep their houses and surrounding quite neat and clean, keep multi colored lights to hail Goddess Laxmi. They do have a faith that Goddess Laxmi does not enter until house is clean.

Ecologically, cow eat grasses, fodders, and agro waste by products like straw including agricultural products which is untapped, unutilized and wastages energy sources available in ecosystem. As part of ecosystem, cow as a primary produced in terms of energy flow perspective in ecological concept. Cow as species help to consume untapped energy and ecologically dependency of human in cow as a part of same ecosystem ultimately helps to survive very easily. Multiple benefits of cow in their ecosystem inspire the cow worshiping. But similar benefits are given by other animals are not mandatory to worship them is because of their religious values and it is a kind of benefits of doubt through anthropological perspective. Here, the worshipping cow in Hindu society is not because of its religious value it is because of the materialistic values. So, getting material benefits from cow as "industry" and provokes as religiously is another dialectism that has mostly practiced in Hindu Society.

In the fourth day of Tihar, Gobardhan Puja or worshipping nature is the main focus of the Tihar. It signifies the importance of flora and fauna in their ecology. Oxen are worshipped on the fourth day of the Tihar. Troops of young boys move from house to house playing the Deusi, like Bhailo played by the girls the evening before. Newars perform Mha Puja, a special ritual in which people worship themselves. Special delicacies are prepared and enjoyed in the form of family meal. Because the body is believed to seal the soul and maintaining a healthy body is a must for the protection of the self, Mha Puja is performed by the Newars. Oxen are used to plough the fields and draw the carts. Govardhan Puja takes place in the country, while for several people it marks the start of the New Year, especially in Newari community. The name of the New Year is Nepal Samvat. So, people worship the oxen on this day. Furthermore, in the evening self is worshipped especially by the Newari people. It is also known as Mha Puja. And this day also worships own body and soul. It is called Mha Puja. The main importance of Govardhan Puja in Nepal is that Ox is known as a vehicle of God Shiva. Ox is used in farming.

Ecologically, mountains are the sources of water and watershed catchment sources, many life including various fauna and many flora are directly or indirectly depend on water resources or say "mountain" as sources of water. Waters 
are recharged in mountains as snow by varying in climatic factors and situations. It is a natural gift to sustain the life of both animal and plant kingdom. Mountain helps to maintain the ecosystem smooth and as sources of water, herbals and plays important role to maintain climate according to the situations. That's why importance of constant sources of water, through mountain significantly provides the water for various purposes to maintain ecosystem. That's why Hindu worships the cow dung as symbol of mountain in Tihar.

Worshiping ox as vehicle of lord Shiva in one way and it is used in ploughing, carrying loads etc also another kind of dialect. Hindu only worship the mountain in one hand and they neglect the sustainable use of water resources, forests, lands which are the major components to preserve the sources of water-mountain. Only exploit and overuse the resources for their own benefits in one hand and ignore the impacts on the ecosystem mainly related with mountain especially watershed and herbals in another hand is also dialectic in nature.

The fifth and final day of Tihar is Bhai Tika. Sisters perform a special ritual and put seven-colored Tika on the foreheads of their brothers. Then they put special flower garlands around the neck of their brothers. This is believed to bestow long life and good health for the brothers.

The last day of Dipawali is called Bhai Tika (the brother's festival)-Sisters do worship their beloved brothers. The fifth day of Tihar, festival is called Bhai Tika. Bhai Tika is celebrated on the last day of Tihar festival of Nepal. Bhai Tika is also called Bhai Duj, Bhai Booj, Bhati Tikaa, Vai Tika, or Bhardutiya etc. These are other names used for Bhai Tika. It also marks the end of the fifth-day long Tihar festival in Nepal. They put Tika on their brothers' forehead and garland round their neck. They also present them the sweets, fruits and other special food item, where as the brothers give their sisters the money, lucrative gifts or clothes in return for the respect bestowed upon them. After then duo brothers and sisters enjoy the succulent dishes together. On Bhai Tika, sisters pray for their brother's happy lives. The main importance of Bhai Tika in Nepal is exchanging love between Didi Bahini with Daju Bhai or brothers and sisters.

Worshiping male or "Bhai Tika" in Nepal stands as one of the very important festival, but ecologically, relations between nature and male is very important. In patriarchy society every socio-cultural system are made for them and they get priority physically and psychologically, similarly male of specific species in ecosystem also play significant role. To continue nature the role of both male and female are important and without ones' another is incomplete. Nature provides the unlimited reproduction capacity with male and limit reproduction capacity with female. The main dialectical approaches that Hindus of Nepal is using in "Bhai Tika" are also one of the most dialectic approaches. Thematically, female should pay the worship culture because they do have limit capacity to reproduce which is rare, but here unlimited capacity of male is worshiped showing dialectic.

To Sum up, Tihar, is a festival of joy and jubilation. This festival is an oppor- 
tunity to strengthen the relationship between brothers and sisters. They exchange cheers and tears. Further, this festival signified the different meaning than Dashain for plural reasons viz-people don't kill birds and animals. They instead worship them in different forms and ways. Similarly, Tihar extends the relationships based on affinal kinships i.e. relationships between sisters and brothers, while Dashain mainly on relationships based on blood i.e. closed kins mainly consanguine and partly affinal while Tihar as vice versa is also a dialectical.

\subsection{Dialectical Anthropological Analysis of Festivals: Dashain and Tihar}

Festivals are not only the phenomena and process of socialization to particular culture in a way in another way they are multi-vocal in nature and they have both manifest and latent meaning of human life. Religious festivals in Nepal which is perceived as traditional, irrational, religious, conservative and older thoughts, events mechanisms, and phenomena and so on, but, critical assessment of them through rational, scientific and modern knowledge system now a day re-define as rational, scientific and advance. The dialectical nature of these festivals, phenomena, mechanism events ultimately helps to maintain society in order. That's why I should incorporate both knowledge systems to understand these both traditional and modern ideas, theories, knowledge and so on to visualize the significance of these traditional festivals through modern and advanced knowledge system. That's why here; I would like to discuss the traditional festivals- Dashain and Tihar as a category for interpreting cultural poetics practices and constitutional element of society and culture, through dialectical anthropological perspective.

From dialectical anthropological perspective, significance of religion to maintain the delegate balance between ecology, population and culture (religion) was artistically presented by Rappaport and Vayda as new methodologies in the 1960s. They focused upon the ecosystem approach, systems functioning, and the flow of energy. These methods rely on the usage of measurements such as caloric expenditure and protein consumption. Careful attention was given to concepts derived from biological ecology, such as carrying capacity, limiting factors, homeostasis, and adaptation. This ecosystem approach remained popular among ecological anthropologists during the 1960s and the 1970s (Milton, 1997).

The Hindu religion generally considers all life forms as sacred, and various species ranging from the tiny insect to gigantic elephant are regarded as equally sacred (Agoramoorthy, 2009). Hinduism has developed sanctity by association for animals such as the swan, eagle and bull that serve as the vehicles of the principal Hindu deities, namely Brahma, the creator, and Vishnu, the protector, Shiva, the regenerator: all three make up the trinity of Hindu Gods. Some of the animals are sacred themselves, such as Hanuman, the monkey God, Naga, the snake God, and Ganesh (Majupuria, 2000).

In the Hindu epic texts, Vishnu incarnates in the form of Mathsya (fish), fol- 
lowed by an amphibious Kurma (turtle). The next incarnation Varaha or wild boar is a terrestrial mammal, depicting how life transferred from the aquatic habitat to the terrestrial environment. Subsequently, Narasimha represents a beast's attempt to attain a human form, which is followed by Vamana, a pigmy human. In the incarnation of Ramachandra, perfect human qualities are identified, while the last one, Kalki, represents the human destruction of the planet giving poor attention to nature (Majupuria, 2000).

Several mythical stories are associated with the sacred animals of Nepal, while pigeons are the favorite animals of Yamaraja, the god of death. He rides on a bull water-buffalo when he visits Earth. Karthikeya, the younger son of Shiva uses peacock for his transportation while the goddess Saraswati, who possesses the powers of speech and wisdom rides a swan. The crow is unique among birds as well since it is well-versed with the happenings in heaven, so people with desires towards paradise try to please it (Waghorne, 1999).

Prehistoric animals such as the crocodile are also given importance in the religion. It is believed that the river Ganges depends on a crocodile for her frequent visits to the Bay of Bengal from the Himalayas. Moreover, the mythical elephant story is well-known: when an elephant named Gajendra was attacked by a crocodile while crossing a river, it screamed for God's help, and Vishnu appeared on his vehicle, Garuda (eagle) and destroyed the hungry reptile. The snake can be seen around the neck of Shiva, the Hindu supreme God (Gupta, 2006).

Dialectical anthropology emphasis on, animal sacrificing as a reality of their food chain in their own ecosystem in one hand and worshipping animal as the acceptance of role of fauna in their ecosystem to maintain delicate balance or say inst's oaths that bind the cosmos and it beings into an order. So, their "worshipping role" ultimately indicates that, we all are the members of the cosmos and we should show the humanity and harmony to each other in one hand and, sacrificing animals in another, the material reality for their adaptation in their environment. That's why religious festivals integrate all diverse elements of society and culture through religions and festivals. Hindu society and culture, is atoministic; divided into isolated, antisocial nuclear families themselves composed of individuals whose view of human nature is fundamentally penurious (poor) avaricious (greedy), materialistic and emphatically egocentric. In this context, for such a fragile relationship (due to outmigration of family member to earn in abroad, gulf and even in India and some cities of the country), Dshain and $T i$ har, offers, societal glues to re- combine and re- unite the family members they scattered and these festivals offers believe in religion either for "hope" or by "fear" for their society and culture.

Rappaport illustrates that "indigenous beliefs in the sacrifice of pigs for the ancestors were a cognized model that produced operational changes in physical factors, such as the size and spatial spread of human and animal populations" (Netting 1996: p. 269). Thus, religion and the kaiko ritual are cybernetic factors that act as a gauge to assist in maintaining equilibrium within the ecosystem 
(Netting, 1996). The Dashain is a ritual of the Hindus during which they slaughter their birds and animals and partake in feasting. The Dashain can be understood easily as "ritual animal slaughter." The "biologization" of the ecological approach that this study represents within cultural anthropology led to the label ecological anthropology, replacing Steward's cultural ecology (Barfield, 1997).

Harris demonstrates that religious taboo makes sense in terms of the local environment, because cattle are important in several ways (Milton, 1997). Thus, the religious taboo is rational, in a materialist sense, because it ensures the conservation of resources provided by the cattle (Milton, 1997). Harris comments upon the classification of numerous cattle as "useless" (Harris, 1998). Ecologically, it is doubtful that any of the cattle are actually useless, especially when they are viewed as part of an ecosystem rather than as a sector of the price market (Harris, 1998).

Likewise in case of festival Tihar, Hindus worship various animals like crow, dog, cow, ox and even human because all are important in their local ecosystem as foundation of their political-economy as well as agencies of psycho- natural system to satisfy their needs socially, culturally and religiously.

One important question is why usually Hindus worship male in most of the religions? Simple answer is because of patriarchy and male domination but exceptionally cow as female animal worshipped in Tihar and various goddesses Durga, Sarashowti, Laxmi etc. sacred role of goddess.

Dashain is worshipped as the maintain the balance of relationship among consanguine kins in primarily and then others according to the degree of Kinship. In Dashain, consanguine relationship got top priority degree of kinship ultimately shows the relation and intimacy. Dashain as mechanism of resolving the stress, and distance between the close members and also works as the means of socialization of members of family and kin groups. Tihar, stands as strengthening the affinal bond (i.e. relationship after marriage between sisters and brothers) with their native home i.e. with consanguine.

Harris further states, “The principal positive ecological effect of India's bovine cattle is in their contribution to production of grain crops, from which about $80 \%$ of the human calorie ration comes" (Harris, 1966). Cattle are the single most important means of traction for farmers. Furthermore, 25,000,000 cattle and buffalo die each year, and this provides the ecosystem with a substantial amount of protein (Harris, 1966). By studying cattle of India with a holistic perspective, Harris provides a strong argument against the claim that these animals are useless and economically irrational.

\section{Conclusion}

Within this diverse cultural, geographical and ecological context, most of the people celebrate Dashain and Tihar. It is found from the study that, there are contradictions or dialectics that were found during field work as:

In Dashain, worshiping goddess, chanting goddess (specific goddess in specif- 
ic day) accordingly with their worship day, praise goddess in one hand and the practice of patriarchy, and male domination, inequalities, and discriminations in another hand ultimately showed the dialects.

In Tihar, Hindus worships crow without touch and there are myths about crow, because crow is the messenger of the Yamaraj (king of devil). Similarly, worshipping dog is also another dialectics; while dog is a placating of Yamaraj; but we keep dog in door and we believe dog is the honest and it provides us security. Among Hindus, cow stands as industry in agricultural society, provides multiple benefits like in transportation, used manure, for milk etc. Here, dialectical framework of Hindus worshipping cows as goddess in one hand and taking benefits materially in other. Likewise, Govardhan Puja is a worshipping nature as mountain is also another dialectical approach to understand the benefits of nature to their own life. Goveradhan Parbat as, abundance of resources, ecology, source of water, source of herbals, multiple benefit but people who live in the Himalaya ecosystem bears very hardship life. Bhai Puja is a kind of exchanging love-emotions between patri-kins to matri-kins, but still there are conflicts between patrifocal and filiafocal practices for patrilineal and matrilineal.

That's why, Hindu worship animals are also rational and they sacrifice animals in Dashain festivals that are also not irrational. Ecological importance of animals must not ignore, because all we are the part of ecosystem and changers in one's adaptation may change in the adaptation of other in same ecosystem because of food chain and energy cycle. So, it is the fact that Dashain and Tihar. are the festivals which are not only important religiously, but it is also important ecologically. The cultural practices like worshipping and sacrificing animal are because of their ecological reason and it is rational too but found dialectical.

\section{Conflicts of Interest}

The author declares no conflicts of interest regarding the publication of this paper.

\section{References}

Agoramoorthy, G. (2009). Sustainable Development: The Power of Water to Ease Poverty and Enhance Ecology. Delhi: Daya Publishing House.

Agoramoorthy, G., \& Hsu, M. J. (2006). Do Animals Suffer Caste Prejudice in Hinduism? Social Compass, 53, 244-245.

Barfield, T. (1997). The Dictionary of Anthropology. Oxford: Blackwell.

Bista, D. B. (1987). People of Nepal. Kathmandu: Ratna Pustak Bhandar.

Bohannan, P., \& Glazer, M. (1988). High Points in Anthropology. New York: McGraw-Hill, Inc.

Craib, I. (1997). Classical Social Theory. London: Oxford University Press.

Cuff, E. C., Francis, D. W., \& Sharrock, W. W. (1990). Perspectives in Sociology. London: Unwin Hyman.

Gupta, S. (2006). Festivals of India. Delhi: Har Anand Publication. 
Harris, M. (1966). The Cultural Ecology of India's Sacred Cattle. Current Anthropology, 7, 51-66. https://doi.org/10.1086/200662

Harris, M. (1979). Cultural Materialism: The Struggle for a Science of Culture. New York: Random House.

Harris, M. (1998). Good to Eat: Riddles of Food and Culture. Long Grove, IL: Waveland Press.

Hawley, H. A. (1950). Human Ecology: A Theory of Community Structure. New York: The Ronald Press Company.

Kathamndu Post (2019). Government Faces a Goat Problem Ahead of Dashain, Import Restrictions and Insufficient Domestic Production Mean Prices Are Likely to Soar. Kathmandu: Kathmandu Post.

Kottak, C. P. (1999). The New Ecological Anthropology. American Anthropologist, 101, 23-35. https://doi.org/10.1525/aa.1999.101.1.23

Leach, E. R. (1968). Dialectic in Practical Redigion. In E. R. Leach (Ed.), Social Anthropology (Vol. 5, P. 207). Cambridge: Cambridge University Press.

Magnarella, P. J. (1982). Cultural Materialism and the Problem of Probabilities. American Anthropology, 84, 138-142. https://doi.org/10.1525/aa.1982.84.1.02a00120

Majupuria, T. C. (2000). Sacred Animals of Nepal \& India. Delhi: Adriot Publishers.

Milton, K. (1997). Ecologies: Anthropology, Culture and the Environment. International Social Sciences Journal, 49, 477-495. https://doi.org/10.1111/j.1468-2451.1997.tb00039.x

Netting, R. M. (1996). Cultural Ecology. In D. Levinson, \& M. Ember (Eds.), Encyclopedia of Cultural Anthropology (pp. 267-271). New York: Henry Holt.

Preece, R. (2001). Animals and Nature: Cultural Myths, Cultural Realities. Vancouver, BC: UBC Press.

Robinson, C. A. (2014). Interpretations of the Bhagavad-Gita and Images of the Hindu Tradition: The Song of the Lord (pp. 8-9). Abingdon-on-Thames: Taylor \& Francis. https://doi.org/10.4324/9780203624517

Salzman, P. C., \& Attwood, D. W. (1996). Ecological Anthropology. In A. Barnard, \& J. Spencer (Eds.), Encyclopedia of Social and Cultural Anthropology (pp. 169-172). London: Routledge.

Seymour-Smith, C. (1986). Dictionary of Anthropology. Boston, MA: G. K. Hall and Company. https://doi.org/10.1007/978-1-349-08037-3

Turner, V. (1967). The Forest of Symbols: Aspects of Ndembu Ritual. Ithaca, London: Cornell University Press.

Waghorne, J. P. (1999). Chariots of the God's: Riding the Line between Hindu and Christian. History of Religions, 39, 95-116. https://doi.org/10.1086/463583 